\title{
The change in the frequency of community acquired acute respiratory tract infections in weight loss period after bariatric surgery: An observational case- crossover study. Are those who have had bariatric surgery at risk?
}

\section{Bariatrik cerrahi sonrası kilo kaybı döneminde toplum kökenli akut solunum yolu enfeksiyonlarının sıklığındaki değişim: bir gözlemsel vaka-çapraz çalışma. Bariatrik cerrahi geçirenler risk altında mı?}

\author{
Serdar Coşkun ${ }^{1}$, Cüneyt Kırkıl ${ }^{1}$, Gamze Kırkıl ${ }^{1}$
}

\begin{abstract}
Abstract while the weight loss process continues after bariatric surgery (BS).

Methods: An observational case-crossover study of 366 patients underwent BS between September 2018 and September 2019 was performed. Prospectively recorded data of ARTI events in the first pre- and post-operative ARTI seasons were compared

Results: Mean age was $36.4 \pm 10.9$ years and mean body mass index (BMI) was $44.1 \pm 6.2 \mathrm{~kg} / \mathrm{m} 2$. Mean change in BMI in an ARTI season was $13.2 \pm 6.1 \mathrm{~kg} / \mathrm{m} 2$. Among 366 patients, 180 (49.2\%) were diagnosed with ARTI and the average numbers of ARTIs was $0.69 \pm 0.85$ in preoperative season. During the postoperative season, 134 $(36.6 \%)$ patients were diagnosed with ARTI and the average numbers of ARTIs was $0.49 \pm 0.76$. Both period prevalence and average number of ARTIs in preoperative ARTI season was significantly higher than postoperative season $(\mathrm{P}=0.001$ for both). The change in BMI in an ARTI season was correlated with the postoperative period prevalence of ARTIs $(\mathrm{r}=0.119, \mathrm{p}=0.022)$.

Conclusion: These findings showed that the period prevalence and incidence of ARTIs reduced after BS However, the frequency of ARTIs was higher in patients with greater weight loss.
\end{abstract}

Keywords: Bariatric surgery, weight loss, acute respiratory tract infection

\footnotetext{
Öz

Amaç: Bariatrik cerrahi (BC) sonrası kilo verme süreci devam ederken, edinilmiş solunum yolu enfeksiyonlarının (ASYE) sıklığında bir artış olup olmadığı bilinmemektedir.

Yöntem: Eylül 2018-Eylül 2019 tarihleri arasında BC uygulanan 366 hastanın gözlemsel vaka-çapraz çalışması yapıldı. Ameliyat öncesi ve sonrası ilk ASYE mevsimlerinde ASYE olaylarının prospektif olarak kaydedilen verileri karşılaştırıldı.

Bulgular: Ortalama yaş 36,4 $\pm 10,9$ yıl, ortalama vücut kitle indeksi (VKİ) 44,1 $\pm 6,2 \mathrm{~kg} / \mathrm{m} 2$ idi. Bir ASYE mevsiminde VKİ'ndeki ortalama değişim $13,2 \pm 6,1 \mathrm{~kg} / \mathrm{m} 2$ idi. 366 hasta arasında $180(\% 49,2)$ ASYE tanısı kondu ve preoperatif sezonda ortalama ASYE sayısı 0,69 $\pm 0,85$ idi. Postoperatif dönemde $134(\% 36,6)$ hastaya ASYE tanısı kondu ve ortalama ASYE sayısı 0,49 \pm 0,76 idi. Preoperatif ASYE sezonunda hem dönem prevalansı hem de ortalama ASYE sayısı postoperatif sezona göre anlamlı derecede yüksekti (her ikisi için de $p$ = 0,001). Bir ASYE mevsiminde VKİ'deki değişim, ASYE'nun postoperatif dönem prevalansı ile korele idi ( $\mathrm{r}=$ $0,119, \mathrm{p}=0,022)$.

Sonuç: Bu bulgular, BC sonrası ASYE prevalansının ve insidansının azaldığını göstermiştir. Bununla birlikte daha fazla kilo kaybı olan hastalarda ASYE sıklığı daha yüksekti.
}

Anahtar kelimeler: Bariatrik cerrahi, kilo kaybı, akut solunum yolu enfeksiyonu ${ }^{1}$ Gazi State Hospital, Department of General Surgery, Samsun, Turkey.

${ }^{2}$ Firat University, Faculty of Medicine, Department of General Surgery, Elazı̆̆, Turkey.

${ }^{3}$ Firat University, Faculty of Medicine, Department of Chest Diseases, Elazığ, Turkey.

SC: 0000-0002-7238-6032

CK: 0000-0001-8756-4850

GK: 0000-0003-4799-5589

Ethics Committee Approval: This study was approved by the Scientific Research Committee of Turkish Ministry of Health (2020-06-06T15_1 8_09).

Etik Kurul Onayı: Bu çalışma için T.C. Sağlık Bakanlığı Bilimsel Araştırma Komitesinden onay alınmıştır (2020-06-06T15_1 8_09).

Conflict of Interest: No conflict of interest was declared by the authors.

Çıkar Çatışması: Yazar çıkar çatışması bildirmemiştir.

Financial Disclosure: The authors declared that this case has received no financial support.

Finansal Destek: Yazarlar bu çalışma için finansal destek almadıklarını beyan etmişlerdir.

Geliș Tarihi / Received: 18.05.2021

Kabul Tarihi / Accepted: 26.07.2021

Yayın Tarihi / Published: 02.08.2021

Sorumlu yazar / Corresponding author: Cüneyt Kırk1

Adres/Address: Furat Üniversitesi Hastanesi, Genel Cerrahi Kliniği, 23119 Elazığ, Turkey.

e-mail: ckirkil@yahoo.com

Tel/Phone: 00905065009933

Copyright $($ ) ACEM 


\section{Introduction}

It is conceivable that in excess of a half million patients globally undergo bariatric procedures each year considering total number of bariatric surgery (BS) is approximately 252,000 in 2018 in USA [1]. Bariatric surgeons and candidates for BS discussed whether individuals who had undergone BS had a higher COVID-19 infection risk due to suppression of immune response in the first weeks of the global outbreak of coronavirus disease 2019 (COVID-19). It was a reasonable question because various forms of stress, trauma, infections, malignancies, and nutritional status could modulate the immune system. It can be thought that the answer of the question should be probably yes, at least during perioperative period. Even if the perioperative immunological response, secondary to tissue injury, anesthesia, and blood transfusion, is not immunosuppressive all the way, it is extensively so [2]. Previous studies that quantify the postoperative immune response have consistently demonstrated that levels of interleukin- 6 and interleukin-10 increased during postoperative period [3, 4]. Early postoperative levels of these cytokines correlate with an increase in the frequency of nosocomial infections.

It is known that adipose tissue takes part in various immune processes due to secretion of pro- and anti-inflammatory factors and causes to obesity-related complications [5]. Bariatric surgery does not only reduce inflammatory state both in adipose tissue and blood by reducing adiposity [6] but also improves comorbidities as T2DM, which is associated with a substantial increase in morbidity and mortality risks associated with acute respiratory tract infections (ARTI) like seasonal influenza [7]. Thus, one can expect that patients who will undergo BS may have metabolic and immune benefits that will be protective in terms of getting ARTI. But could the same thing be told for patients who were still in the process of weight loss? They had still some extra fat tissue which could produce pro- and antiinflammatory factors. Moreover, they could be at a higher risk because of their nutritional status.

Until now, there is no data in literature about rates of community acquired ARTIs during weight loss period following BS. There are some seasonal differences in the epidemiological data of ARTIs around countries. In Turkey, ARTIs occur mostly in the period between late September and April [8]. And weight loss rate is not constant following $\mathrm{BS}$. The vast majority of patients lose weight faster in early period. Hypothetically, there might be a difference for getting ARTIs among patients related to the month of surgery. Non-seasonal ARTIs could have an effect on the results.

In the present study, it was aimed to detect whether there was any change in the frequency of ARTIs in a common ARTIs season while weight loss process was still going on following a BS.

\section{Material and methods}

\section{Patients}

Prospectively recorded data of 423 patients who underwent BS by a single surgeon between September 2018 and September 2019 were analyzed retrospectively. Compliance with the validated international criteria for BS as having body mass index $(B M I) \geq 40 \mathrm{~kg} / \mathrm{m} 2$ or $\geq 35 \mathrm{~kg} / \mathrm{m} 2$ in the presence of obesity-related medical co-morbidities was the inclusion criteria for the study. Exclusion criteria were noncompliance with BS criteria and follow-up protocols, and flu vaccination history. Informed consent was obtained from all individuals included in the study. All smokers were advised to quit smoking after surgery.

\section{Follow-up}

Patients followed by a team composed of two clinical secretaries, a nurse, and a medical doctor. The postoperative follow-up protocol for first year was as follows. Body weight was recorded monthly. Complete blood count, liver function tests, blood levels of glucose, glycated hemoglobin, urea, creatinine, sodium, potassium, calcium, albumin, ferritin, thiamine, folic acid, cyanocobalamin, and 25-hydroxyvitamin D levels were measured in the first postoperative month, and were repeated by 3-months intervals for the first postoperative year by their own primary care physicians. Doses of supplements were adjusted according to the test results by the medical doctor in bariatric team. Complete remission of T2DM defined as a level of glycated hemoglobin less than $6.0 \%$ without any anti-diabetic medication in the postoperative period.

\section{Data acquisition}

After obtaining approval from the Scientific Research Committee of Turkish Ministry of Health (2020-06-06T15_1 8_09), data for ARTI of all patients were obtained in June 2020 from the electronic database of Turkish Ministry of Health (enabiz). The database gets data from the Social Security Institution (SSI), the only organization that provides public health insurance in Turkey. Every physician work in primary care clinics, public hospitals, and private hospitals contracted with SSI have to enter the data of pre- and definitive diagnosis into the database of SSI using International classification of diseases (ICD) version 10. ARTI-related diagnoses in the first September-April period before and after operation date were evaluated. Data of the postoperative 30-days was not included for the probability of hospital-acquired infection. In June 2020, the clinical secretaries called the patients for getting information about flu vaccine (within one year before or after surgery), and smoking status.

\section{Statistical analysis}

The results were presented as mean, ratio, per cent or dichotomy. Distributions of parameters were evaluated by Kolmogorov-Smirnov test. Student's T-test was used for the comparisons of parametric data, and chi-square test was used for the comparisons of non-parametric data. The bivariate analysis was used to evaluate the correlations between age, T2DM, chronic pulmonary diseases, smoking, BMI, delta $(\Delta)$ BMI (change in BMI) in a season of ARTI, percentage excess weight loss $(\% \mathrm{EWL}=100 \% \times$ [baseline weight - last weight $]$ [baseline weight - ideal weight]) and ARTIs. A simple linear regression analysis was used for correlation between BMI and $\Delta$ $\mathrm{BMI}$ in season. All calculations were performed using the IBM SPSS version 22 (IBM Corporation, Chicago, IL, USA). A 2tailed $\mathrm{P}$ value less than 0.05 was considered statistically significant. Power analysis was performed by G Power 3.1.9.2 (written by Franz Faul, Universität Kiel, Germany).

\section{Results}

The flow chart of patient enrollment is shown in Figure 1. Gastroesophageal reflux was sole indication for revisional surgery for three patients with a BMI less than $31 \mathrm{~kg} / \mathrm{m} 2$. They were excluded because they would not be expected to lose too much weight. Others met the validated international criteria for bariatric surgery. Because of noncompliance with follow-up protocols, additional 49 patients were excluded. Because of flu vaccination history within one year, 5 patients were also excluded. The remaining 366 patients received multivitamin and iron supplements at least 9 months during postoperative period were enrolled into the study. Table 1 summarizes preoperative characteristics and the changes in demographics of patients 
during postoperative follow-up. Mean postoperative follow-up was $13.2 \pm 3.4$ months (range, 8 to 19 ), but a mean of $11.0 \pm 1.4$ months (range, 8 to 12) was in the ARTI season. Mean \%EWL was $90.1 \% \pm 19.4 \%$ (range, $31 \%$ to $141 \%$ ) during follow-up. Mean of $\Delta$ BMI in a season was $13.2 \pm 6.1 \mathrm{~kg} / \mathrm{m} 2$ (range, 0.8 to 32.2). There was a significant correlation between baseline BMI and $\Delta \mathrm{BMI}$ in a season $(\mathrm{Beta}=0.563,95 \% \mathrm{CI},-0.50$ to $0.78, \mathrm{P}=$ 0.000 ). Since the patients who had surgery towards the end of ARTI season lost the majority of their excess weight in summer when ARTIs were not common, they had a lower $\triangle$ BMI in the next ARTI season. Among 70 patients with T2DM, 61 (87.1\%) had complete remission in the postoperative 3rd month. All but one of the remaining patients stopped using insulin treatment. Indeed, a reduction in the insulin doses and glycated hemoglobin levels were recorded for this patient. Although 10 smokers $(16.1 \%)$ quit smoking in postoperative period, smoking rates were not statistically different in both periods $(16.9 \%$ in preoperative period vs. $14.2 \%$ in postoperative period, $\mathrm{p}=0.359)$.

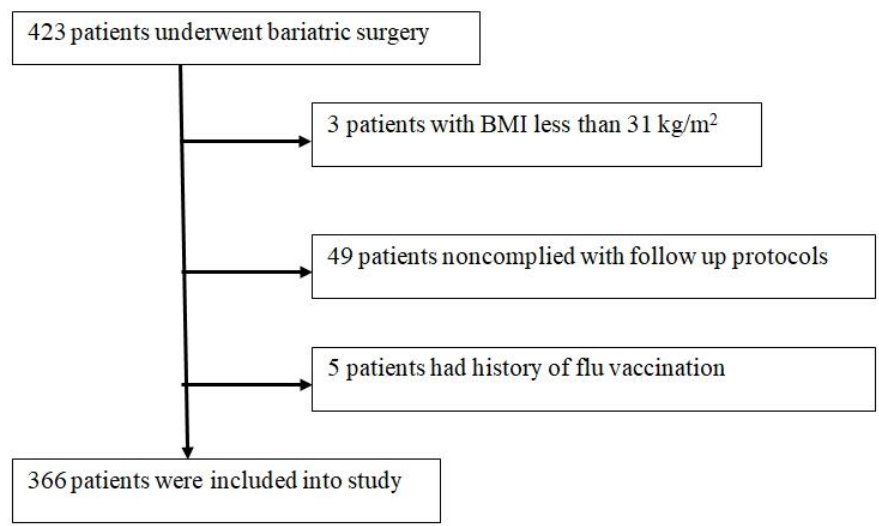

Figure 1. The flow chart illustrating patient enrollment.

Table 1. The preoperative characteristics and the changes in demographics of patients during postoperative follow-up.

\begin{tabular}{|c|c|c|c|}
\hline & $\begin{array}{c}\text { Preoperative } \\
(\mathrm{n}=366)\end{array}$ & $\begin{array}{l}\text { Postoperative } \\
\quad(\mathrm{n}=366)\end{array}$ & $P$ value \\
\hline Age (years) (mean \pm SD) & $36.4 \pm 10.9$ & $37.3 \pm 10.9$ & 0.258 \\
\hline $\operatorname{Sex}(\mathrm{F} / \mathrm{M})$ & \multicolumn{2}{|c|}{$268 / 98$} & NA \\
\hline $\begin{array}{l}\mathrm{BMI}\left(\mathrm{kg} / \mathrm{m}^{2}\right)(\text { mean } \pm \\
\mathrm{SD})\end{array}$ & $44.1 \pm 6.2$ & $27.8 \pm 4.5$ & $<0.001$ \\
\hline $\begin{array}{l}\text { Type } 2 \text { Diabetes Mellitus } \\
\text { (yes / no) }\end{array}$ & $70 / 296$ & $9 / 357$ & $<0.001$ \\
\hline Chronic Pulmonary & $16 / 350$ & $16 / 350$ & 1.000 \\
\hline Disease (yes / no) & & & \\
\hline Smoking (yes / no) & $62 / 304$ & $52 / 314$ & 0.359 \\
\hline ARTIs (yes / no) & $180 / 186$ & $134 / 232$ & 0.001 \\
\hline $\begin{array}{l}\text { Average number of ARTIs } \\
(\text { mean } \pm \mathrm{SD})\end{array}$ & $0.69 \pm 0.85$ & $0.49 \pm 0.76$ & 0.001 \\
\hline \multicolumn{4}{|l|}{ Operations } \\
\hline SG $(\%)$ & $270(73.8)$ & & \\
\hline OAGB $(\%)$ & $40(10.9)$ & & \\
\hline RYGB (\%) & $20(5.5)$ & & \\
\hline TB $(\%)$ & $18(4.9)$ & & \\
\hline Revisional RYGB (\%) & $16(4.4)$ & & \\
\hline BPD-DS (\%) & $2(0.5)$ & & \\
\hline
\end{tabular}

BMI: Body mass index, ARTI: Acute respiratory tract infection, SG: Sleeve gastrectomy,

OAGB: One anastomosis gastric bypass, RYGB: Roux-en-Y gastric bypass, TB: Transit bipartition with sleeve gastrectomy, BPD-DS: Biliopancreatic diversion with duodenal switch.

Among 366 patients, 180 (49.2\%) were diagnosed with ARTI at least one, at most, five times in the last preoperative ARTI season. During the first ARTI season after surgery, 134 (36.6\%) patients were diagnosed with ARTI (maximum three times in a season). All ICD-10 codes used to diagnose both preoperative and postoperative ARTI seasons were listed in table 2. The most common ICD-10 codes were J06 and J20 in both periods. The period prevalence (number of persons with an episode of ARTI over a defined period of time / number of persons in the population over the same period) in preoperative
ARTI season was significantly higher than postoperative season ( $49.2 \%$ vs. $36.6 \%$, respectively, $\mathrm{P}=0.001)$. The postoperative period prevalence of patients operated during ARTI season (between September and April) was similar to those operated in post-ARTI season (between May and August) (86 / 228, 37.7\% vs. $48 / 138,34.8 \%$, respectively, $\mathrm{P}=0.654)$. The average numbers of ARTIs per cohort were also significantly reduced. It was $0.49 \pm 0.76$ in postoperative season, while it was $0.69 \pm 0.85$ in preoperative season $(\mathrm{P}=0.001)$. So, incidence proportions for ARTIs were $69 \%$ and $49 \%$ per an ARTI season in preoperative and postoperative periods, respectively. Considering the average numbers of ARTIs, the effect size was 0.25 and power of the study was 99.9 percent.

Table 3 summarizes the correlations between ARTIs and risk factors. Bivariate analysis for preoperative period showed that the period prevalence of ARTIs was negatively correlated with age and T2DM $(r=-0.122, \mathrm{P}=0.02$ and $\mathrm{r}=$ $0.173, \mathrm{P}=0.001$, respectively). Sex, BMI, having chronic pulmonary diseases, and smoking habit were not correlated with the period prevalence of ARTIs. While the preoperative frequency of ARTIs was negatively correlated with age $(\mathrm{r}=$ $0.133, \mathrm{P}=0.011)$, it was positively correlated with BMI $(\mathrm{r}=$ $0.104, \mathrm{P}=0.048$ ). There was no correlation between the preoperative frequency of ARTIs and sex, T2DM or chronic pulmonary diseases, and smoking habit. In the postoperative ARTI season, there was no correlation between postoperative ARTIs frequency and sex, T2DM, smoking habit, baseline BMI, and operation type. Both the period prevalence and incidence of ARTIs was negatively correlated with age and chronic pulmonary diseases as a comorbidity $(\mathrm{P}<0.05$ for all). There was a positive correlation between $\triangle \mathrm{BMI}$ in ARTI season and the period prevalence of ARTIs $(r=.119, \mathrm{P}=0.022)$. There were also strong correlations between preoperative and postoperative periods in both the period prevalence and incidence proportions $(\mathrm{r}=0.364, \mathrm{P}=0.000$, for prevalence, and $\mathrm{r}=0.334, \mathrm{P}=0.000$, for incidence). Among 134 patients who had ARTIs in postoperative period, $98(73.1 \%)$ had also ARTIs in preoperative period. Only one-fifth of the patients $(19.4 \%)$ who had not any ARTIs in the preoperative period experienced ARTIs in the first postoperative ARTI season.

Table 2. The distribution of acute respiratory tract infections in preoperative and postoperative periods.

\begin{tabular}{llcc}
$\begin{array}{l}\text { ICD-10 } \\
\text { codes }\end{array}$ & Diagnosis & $\begin{array}{r}\text { Preoperative } \\
\text { cases (n) }\end{array}$ & $\begin{array}{c}\text { Postoperative } \\
\text { cases (n) }\end{array}$ \\
\hline J00 & Acute nasopharyngitis (common & 18 & 8 \\
J01 & cold) & 32 & 25 \\
J02 & Acute sinusitis & 29 & 24 \\
J03 & Acute pharyngitis & 8 & 4 \\
& Acute upper respiratory infections & & 61 \\
J06 & of multiple and unspecified sites & 72 & 6 \\
J11 & Influenza & 11 & 6 \\
J18 & Pneumonia & 16 & 40 \\
J20 & Acute bronchitis & 57 & 6 \\
& Unspecified acute lower respiratory & 11 & 180 \\
J22 & infection & 254 & \\
\hline Total & & & \\
\hline ICD-10: International Classification of Diseases version 10 & &
\end{tabular}

ICD-10: International Classification of Diseases version 10

\section{Discussion}

In the present study, it was observed that the period prevalence and incidence of ARTIs were significantly reduced in weight loss period following BS. BMI was positively correlated with the incidence of ARTIs in preoperative season. $\triangle \mathrm{BMI}$ in ARTI season was also positively correlated with the period prevalence of ARTIs postoperatively. It was associated with higher baseline BMI in these patients. 
It is well known that being overweight $(\mathrm{BMI}=25.0-$ $29.9 \mathrm{~kg} / \mathrm{m} 2)$ and in particular obesity (BMI $\geq 30 \mathrm{~kg} / \mathrm{m} 2)$ have a role in predisposition to RTIs [9,10]. Moreover, two recent Danish population-based studies reported an excess of a large spectrum of RTIs including pneumonia among obese people $[11,12]$. Some obesity-related mechanisms can alter immune system, and lead to predisposition to infections. Obesity is characterized by excessive accumulation of fat tissue. Adipokines produced by adipocytes primarily composing adipose tissue can significantly alter immune function. Adiponectin is a member of adipokines and reduces macrophage activity and proinflammatory cytokine production. Its production decreases in obese patients. Whereas, leptin that is also a member of adipokines is considered to be proinflammatory, and is elevated in obese individuals. The anti-inflammatory action of adiponectin is partly attributed to the induction of interleukin 10 and the suppression of nuclear factor $\mathrm{kB}$ in macrophages. Thus, it suppresses of $\mathrm{T}$ cell-mediated responses and innate immune responses. When they were dealt as a whole, low plasma levels of adiponectin causes overresponse of the innate immune system to pathogens [13]. It results in more pronounced immune response against to viruses in obese persons than that of lean persons, and can explain why the courses of some ARTIs like COVID-19 and H1N1 are severe in obese patients. One explanation for obesity and ARTIs relationship is increased vulnerability to infections in obese individuals. The vast majority of evidence is found regarding nosocomial infections, except for the findings in influenza pandemics. It is caused by lack of retrieving record, because BMI is not usually recorded in health care providers in the case of community acquired infections [14]. But it has shown that obesity affected the influenza course and increased mortality rate during the influenza $\mathrm{H} 1 \mathrm{~N} 1$ pandemic [15]. In the present study, there was no mortality caused by ARTIs. Both the period prevalence and incidence of ARTIs decreased in obese patients treated with BS.

Table 3. The correlations between the frequency of ARTIs and risk factors in both preoperative and postoperative seasons.

\begin{tabular}{|c|c|c|c|c|c|}
\hline & & \multicolumn{2}{|c|}{ Preoperative } & \multicolumn{2}{|c|}{ Postoperative } \\
\hline & & Prevalence & Incidence & Prevalence & Incidence \\
\hline \multirow[t]{2}{*}{ Age } & $\mathrm{r}$ & -0.122 & -0.133 & -0.103 & -0.124 \\
\hline & $\mathrm{p}$ & $0.020 *$ & $0.011 *$ & $0.049 *$ & $0.018 *$ \\
\hline \multirow[t]{2}{*}{ Sex } & $\mathrm{r}$ & -0.052 & 0.029 & 0.027 & 0.047 \\
\hline & $\mathrm{p}$ & 0.323 & 0.582 & 0.605 & 0.369 \\
\hline \multirow{2}{*}{$\begin{array}{l}\text { Type } 2 \text { diabetes } \\
\text { mellitus }\end{array}$} & $\mathrm{r}$ & -0.173 & -0.086 & -0.084 & -0.056 \\
\hline & $\mathrm{p}$ & $0.001 \dagger$ & 0.099 & 0.108 & 0.283 \\
\hline \multirow[t]{2}{*}{$\begin{array}{l}\text { Chronic pulmonary } \\
\text { diseases }\end{array}$} & $\mathrm{r}$ & -0.050 & -0.017 & -0.107 & -0.103 \\
\hline & $\mathrm{p}$ & 0.341 & 0.741 & $0.041 *$ & $0.049 *$ \\
\hline \multirow[t]{2}{*}{ Smoking } & $\mathrm{r}$ & 0.051 & 0.094 & 0.048 & 0.066 \\
\hline & $\mathrm{p}$ & 0.329 & 0.073 & 0.359 & 0.207 \\
\hline \multirow[t]{2}{*}{ BMI baseline } & $\mathrm{r}$ & 0.091 & 0.104 & 0.073 & -0.007 \\
\hline & $\mathrm{p}$ & 0.081 & $0.048 *$ & 0.164 & 0.894 \\
\hline \multirow[t]{2}{*}{ Type of operation } & $\mathrm{r}$ & NA & NA & -0.067 & 0.012 \\
\hline & $\mathrm{p}$ & & & 0.366 & 0.869 \\
\hline \multirow{2}{*}{ EWL percent } & $\mathrm{r}$ & NA & NA & 0.083 & 0.130 \\
\hline & $\mathrm{p}$ & & & 0.111 & $0.013 *$ \\
\hline \multirow[t]{2}{*}{$\Delta \mathrm{BMI}$ in season } & $\mathrm{r}$ & NA & NA & 0.119 & 0.032 \\
\hline & $\mathrm{p}$ & & & $0.022 *$ & 0.537 \\
\hline \multirow[t]{2}{*}{ BMI last } & $\mathrm{r}$ & NA & NA & -0.052 & 0.005 \\
\hline & $\mathrm{p}$ & & & 0.317 & 0.931 \\
\hline \multirow{2}{*}{$\begin{array}{l}\text { Preoperative } \\
\text { prevalence }\end{array}$} & $\mathrm{r}$ & NA & NA & 0.364 & 0.269 \\
\hline & $\mathrm{p}$ & & & $0.000 \ddagger$ & $0.000 \ddagger$ \\
\hline \multirow{2}{*}{$\begin{array}{l}\text { Preoperative } \\
\text { incidence }\end{array}$} & $\mathrm{r}$ & NA & NA & 0.340 & 0.334 \\
\hline & $\mathrm{p}$ & & & $0.000 \$$ & $0.000 \div$ \\
\hline
\end{tabular}

applicable, $* \mathrm{p}$ value less than $0.05, \dagger \mathrm{p}$ value equals to $0.001, \$ \mathrm{p}$ value less than 0.001

In this study, it was observed that most of the patients who had ARTI in the preoperative period also experienced ARTI in the postoperative period. This observation in the weight-losing obese population suggests that there are some risk factors other than obesity that predispose to ARTIs. The risk factors as living in crowded conditions, malnutrition, lack of immunization, and exposure to tobacco or indoor smoke may contribute the development of ARTIs [16]. The patients included into the study had not immunization history for influenza that was a common cause of ARTIs. Cigarette smoking has been reported as a major environmental risk factor for recurrent and severe RTIs [17,18]. Although there were patients who quit smoking in this cohort, the decrease in the frequency of smoking was not statistically significant. Smoking habit was not correlated with the period prevalence and incidence of ARTIs. It is known that individuals with diabetes are also at risk of infections as influenza and pneumonia [19]. Nevertheless, there was also no positive correlation between T2DM and the period prevalence and incidence of ARTIs in the study. A reduction in the frequency or severity of acute respiratory infections might be expected in weight losing obese patients for the reasons mentioned earlier. However, weight loss process following BS is actually a period when the energy balance is negative. Malnutrition is considered the most common cause of immunodeficiency throughout the World. It can facilitate pathogen invasion and propagation by compromising host defense [20]. The nutritional status of the host has critical importance for the outcome of infection. Because initiation of both innate and adaptive immune responses requires additional anabolic energy and it has been shown that acute protein-energy malnutrition can affect immune response at various stages [21]. The positive correlation between change in BMI in a season and postoperative ARTIs that was observed in this study might be due to energy deficit following BS. However, the malnutrition-infection relationship is not only based on energy deficit. Both the adaptive and innate arms of the immune system are adversely affected by different types of nutritional deficiency state. It has been shown that vitamin A or vitamin D deficient children are at risk of developing more frequent and more severe respiratory tract infections $[22,23]$. Vitamin $\mathrm{C}$ also reduces severity of cold by perhaps improving natural killer cells and lymphocyte activities [24]. Similarly, deficiencies of fatty acids, amino acids, iron, and trace elements also increases susceptibility to major human infectious diseases [21]. It can be said that the patients having energy deficit in the present cohort were protected from ARTIs by the protective effect of regularly used multivitamin supplements in the postoperative period. The decrease in the incidence of ARTIs in smokers and patients with T2DM, although not statistically significant, can also be attributed to multivitamin and mineral supplements. But it is impossible to place a final judgement, because postoperative levels of vitamins and minerals were analyzed in different laboratories using various methods in primary care clinics.

Having a chronic pulmonary disease is another important risk factor for ARTIs [25]. Chronic diseases, foremost asthma and chronic obstructive pulmonary diseases, are associated with both an increased risk of RTIs and obesity [2629]. Interestingly, it was negatively correlated with both the period prevalence and incidence of ARTIs in postoperative period. This observation may be due to the protective effect of vitamin supplements, or may be due to changes in patients' awareness of health or self-protection efforts from diseases in the postoperative period. But also, it may be due to inappropriate using of ICD-10 codes by health care providers, such as using of acute exacerbation of chronic pulmonary disease diagnosis code (J44) instead of any ARTIs code. The overlapping clinical syndromes caused by the etiologic agents of acute respiratory infections make it difficult to assign a specific etiology based on the clinical presentations [30]. Physicians dealing with ARTIs do not usually make an effort to identify the microorganism causing infection. They endeavor to identify pathogens only for pandemics or epidemiological studies, though public databases 
are important for determining the variables that affect public health and making decisions about public health. Moreover, a lot of people prefer to use some over-the-counter medications instead of consulting a doctor in flu-like conditions. Nonspecific clinical presentation, and a lack of medical attention or recordkeeping cause to underestimation of ARTIs. For these reasons, it does not seem possible to reliably determine the prevalence and incidence of acute respiratory tract infections.

This study has some limitations, firstly it has a retrospective design. The possibility of the presence of patients who do not apply a health care provider in the case of any ARTIs, and the possibility of misused ICD-10 codes by healthcare professionals are other limitations. However, data of the cohort includes all applications to family doctors, state hospitals, university hospitals, and private hospitals contracted with SSI. Another limitation is that the prevalence of influenza like illness in the population varies between years due to epidemiological reasons. Indeed, considering Turkish Ministry of Health data, the frequency of influenza-like illness doubled between 2017-2018 (2017/week 40th to 2018/week 20th) and 2018-2019 (2018/week 40th to 2019/week 20th) seasons (Figure 2) [31]. The data for 2019-2020 season has not yet been reported by Turkish Ministry of Health. Despite this increase between two seasons, the decrease in prevalence and incidence of ARTIs in patients who lost weight following BS is remarkable. This is the first study focused on the effect of weight losing following BS on the seasonal ARTIs, and it may enable physicians to do comment whether BS reduces in the frequencies of ARTIs like H1N1 or COVID-19.

As a conclusion, the frequency of ARTIs decreased while weight loss continued after BS in this retrospective cohort of adults receiving vitamin and mineral supplements. Further studies are needed to determine whether ARTIs decrease in patients with vitamin or mineral deficiencies in postoperative period. Sub-group analysis should be included in future studies for the risk factors predisposing to ARTIs such as socioeconomic status, living and working conditions, and nutritional parameters of patients. Based on these findings, it can be said that patients with a history of BS are expected to be less likely to get COVID19 than obese patients, unless they have vitamin or mineral insufficiency.

\section{References}

1. English WJ, DeMaria EJ, Hutter MM, Kothari SN, Mattar SG et al. American Society for Metabolic and Bariatric Surgery 2018 estimate of metabolic and bariatric procedures performed in the United States. Surg Obes Relat Dis. 2020; 16(4): 457- 463.
2. Torrance HDT, Pearse RM, O’Dwyer MJ. Does major surgery induce immune suppression and increase the risk of postoperative infection? Curr Opin Anaesthesiol. 2016; 29(3): 376-383.

3. Baigrie RJ, Lamont PM, Kwiatkowski D, Dallman MJ, Morris PJ. Systemic cytokine response after major surgery. Br J Surg. 1992; 79(8): 757-760.

4. Klava A, Windsor AC, Farmery SM, Woodhouse LF, Reynolds JV et al. Interleukin-10. A role in the development of postoperative immunosuppression. Arch Surg. 1997; 132(4): 425- 429.

5. Mraz M, Haluzik M. The role of adipose tissue immune cells in obesity and low-grade inflammation. J Endocrinol. 2014; 222(3): R113- 127.

6. Poitou C, Dalmas E, Renovato M, Benhamo V, Hajduch F et al. CD14dimCD16+ and CD14+CD16+ monocytes in obesity and during weight loss: relationships with fat mass and subclinical atherosclerosis. Arterioscler Thromb Vasc Biol. 2011; 31(10): 2322- 2330.

7. Mertz D, Kim TH, Johnstone J, Lam P-P, Science M et al. Populations at risk for severe or complicated influenza illness: systematic review and meta-analysis. Br Med J 2013; 347: f5061.

8. Çiçek C, Arslan A, Karakuş HS, Yalaz M, Saz EU, Pullukçu $\mathrm{H}$, Çok G. Akut solunum yolu enfeksiyonu olan hastalarda solunum viruslarının prevalansı ve mevsimsel dağılımı, 2002 2014 [Prevalence and seasonal distribution of respiratory viruses in patients with acute respiratory tract infections, 2002-2014]. Mikrobiyol Bul. 2015 Apr;49(2):188-200. Turkish. doi: 10.5578/mb.9024. PMID: 26167819.

9. Han YY, Forno E, Gogna M, Celedon JC. Obesity and rhinitis in a nationwide study of children and adults in the United States. J Allergy Clin Immunol Pract. 2016; 137(5): 1460 1465.

10. Cocoros NM, Lash TL, DeMaria A Jr, Klompas M. Obesity as a risk factor for severe influenza-like illness. Influenza Other Respir Viruses. 2014; 8(1): 25- 32.

11. Kaspersen KA, Pedersen OB, Petersen MS, Hjalgrim H, Rostgaard $\mathrm{K}$ et al. Obesity and risk of infection: results from the Danish blood donor study. Epidemiology. 2015; 26(4): 580-589.

12. Harpsoe MC, Nielsen NM, Friis-Moller N, Andersson M, Wohlfahrt $\mathrm{J}$ et al. Body mass index and risk of infections among women in the Danish National Birth Cohort. Am J Epidemiol. 2016; 183(11): 1008- 1017.

13. Tsatsanis C, Margioris AN, Kontoyiannis DP. Association between H1N1 infection severity and obesity-adiponectin as a potential etiologic factor. J Infect Dis. 2010; 202(3): 459460.

14. Huttunen R, Syrjänen J. Obesity and the outcome of infection. Lancet Infect Dis. 2010; 10(7): 442- 443.

15. Huttunen R, Syrjänen J. Obesity and the risk and outcome of infection. Int J Obes. 2013; 37(3): 333-340.
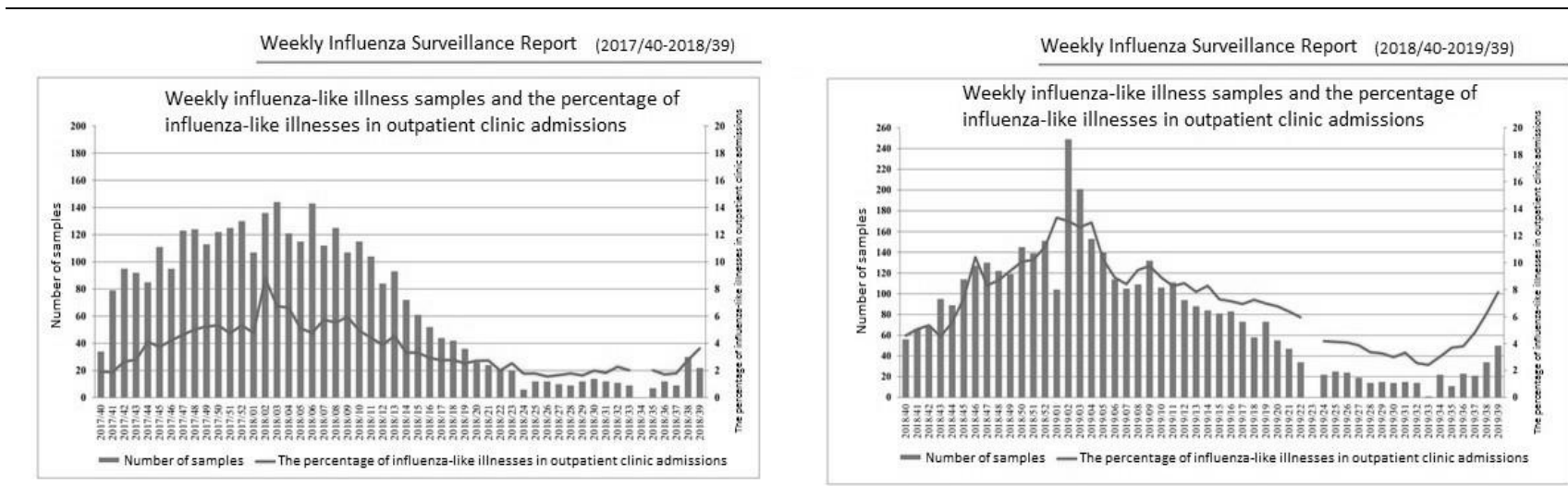

Figure 2. The change in frequency of influenza-like illness in Turkey between 2017-2018 and 2018-2019 influenza seasons (https://www.grip.gov.tr/tr/2017-2018-haftalik-influenza-raporlari.html) 
16. Ferkol T, Schraufnagel D. The Global Burden of Respiratory Disease. Ann Am Thorac Soc. 2014; 11(3): 404- 406.

17. Arcavi L, Benowitz NL. Cigarette smoking and infection. AMA Arch Intern Med. 2004; 164(20): 2206- 2216.

18. Huttunen R, Heikkinen T, Syrjanen J. Smoking and the outcome of infection. J Intern Med. 2011; 269(3): 258-269.

19. Gupta R, Ghosh A, Singh AK, Misra A. Clinical considerations for patients with diabetes in times of COVID19 epidemic. Diabetes Metab Syndr. 2020; 14(3): 211- 212.

20. Rodriguez L, Cervantes E, Ortiz R. Malnutrition and Gastrointestinal and Respiratory Infections in Children: A Public Health Problem. Int J Environ Res Public Health. 2011; 8(4): 1174-1205.

21. Schaible UE, Kaufman SHE. Malnutrition and infection: complex mechanisms and global impacts. PLoS Med. 2007; 4(5): e115.

22. Sirisinha $\mathrm{S}$. The pleotropic role of vitamin $\mathrm{A}$ in regulating mucosal immunity. Asian Pac J Allergy Immunol. 2015; 33(2): 71- 89.

23. Cannell JJ, Vieth R, Umhau JC, Holick MF, Grant WB et al. Epidemic influenza and vitamin D. Epidemiol Infect. 2006; 134(6): 1129- 1140 .

24. Johnston CS, Barkyoumb GM, Schumacher SS. Vitamin C supplementation slightly improves physical activity levels and reduces cold incidence in men with marginal vitamin $\mathrm{C}$ status: a randomized controlled trial. Nutrients 2014; 6(7): 25722583.

25. Jafarinejad H, Moghoofei M, Mostafaei S, Salimian J, Jamalkandi SA, Ahmadi A. Worldwide prevalence of viral infection in AECOPD patients: A metaanalysis. Microb Pathog. 2017; 113: 190- 196.

26. Sethi S. Infection as a comorbidity of COPD. Eur Respir J. 2010; 35(6): 1209-1215.

27. Franssen FM, O'Donnell DE, Goossens GH, Blaak EE, Schols AM. Obesity and the lung: 5. Obesity and COPD. Thorax 2008; 63(12): 1110- 1117.

28. Sutherland ER. Linking obesity and asthma. Ann N Y Acad Sci. 2014; 1311: 31-41.

29. James KM, Peebles RS Jr, Hartert TV. Response to infections in patients with asthma and atopic disease: an epiphenomenon or reflection of host susceptibility? J Allergy Clin Immunol Pract. 2012; 130(2): 343-351.

30. Chicaiza-Ayala W, Henríquez-Trujillo AR, Ortiz-Prado E, Douce RW, Coral-Almeida M. The burden of acute respiratory infections in Ecuador 2011-2015. PLoS One. 2018 May 1;13(5):e0196650.

31. https://www.grip.gov.tr/tr/2017-2018-haftalik-influenzaraporlari.html (access date: August 1, 2020). 